\title{
Media Audio Visual sebagai Upaya Meningkatkan Hasil Belajar Fikih di MI Roudhotul Huda Sekaran Gunungpati
}

\author{
Shofi Rouyani*, Aris Abdul Ghoni, dan Linda Indiyarti Putri \\ Universitas Wahid Hasyim Semarang \\ *Email korespondensi: shofirouyani1997@gmail.com
}

\begin{abstract}
Audio visual media is one of the popular learning media used in schools. One of the advantages of using audio-visual learning media includes minimizing teaching and learning activities which are dominated verbally and all students are expected to have the same experience in learning. The formulations of the problems in this research are: 1) How is the implementation of Fiqh learning at MI Roudhotul Huda Sekaran Gunungpati? 2) How is the student achievement in the class II Islamic Fiqh lesson at MI Roudhotul Huda Sekaran Gunungpati? 3) How is the effectiveness of the audio-visual learning media in Islamic Civilization History class II students of MI Roudhotul Huda Sekaran Gunungpati? This research method is Classroom Action Research using research design by Kemmis and Mc. Taggart. With a KKM value of 70, the results of the study proved that the learning outcomes of students in the pre-cycle were only 38\% who experienced completeness. In the first cycle, it increased to 97\% who experienced completeness. Then it was continued in cycles II and III with the acquisition of a learning completeness rate of $100 \%$.
\end{abstract}

Keyword: Audio Visual Media, CAR, Figh Lessons

\section{Abstrak}

Media audio visual adalah salah satu media pembelajaran yang populer digunakan di sekolah. Salah satu kelebihan menggunakan media pembelajaran audio visual antara lain meminimalisir kegiatan belajar mengajar yang didominasi secara verbal dan semua peserta didik diharapkan mendapat pengalaman yang sama dalam pembelajaran. Rumusan masalah dalam penelitian ini adalah: 1) Bagaimana pelaksanaan pembelajaran Fikih di MI Roudhotul Huda Sekaran Gunungpati? 2) Bagaimana prestasi belajar siswa pada pelajaran Fikih siswa kelas II MI Roudhotul Huda Sekaran Gunungpati? 3) Bagaimana efektivitas media pembelajaran audio visual pada pelajaran Fikih siswa kelas II MI Roudhotul Huda Sekaran Gunungpati? Metode penelitian ini adalah Penelitian Tindakan Kelas menggunakan desain penelitian Kemmis dan Mc. Taggart. Dengan nilai KKM 70, hasil penelitian membuktikan bahwa hasil belajar peserta didik pada pra siklus hanya sebesar 38\% yang mengalami ketuntasan. Pada siklus I meningkat menjadi 97\% yang mengalami ketuntasan. Kemudian dilanjutkan pada siklus II dan III dengan perolehan angka ketuntasan belajar sebesar 100\%.

Kata kunci: Media Audio Visual, PTK, Pelajaran Fikih 


\section{A. Pendahuluan}

Belajar merupakan proses internal yang kompleks, melibatkan ranah kognitif, afektif, dan psikomotorik. Proses belajar tersebut mengaktualisasikan ranah-ranah tersebut tertuju pada bahan belajar tertentu (Dimyati dan Mudjiono, 2009). Sedangkan guru guru berperan sebagai penanggung jawab perkembangan peserta didik dalam mengupayakan perkembangan potensi anak didik dalam aspek kognitif, afektif, dan psikomotorik sampai setinggi-tingginya (Ahmad Tafsir, 2004).

Proses belajar yang baik tidak hanya sekedar menghafal namun disarankan peserta didik digiring untuk dapat membangun pengetahuannya sendiri (Khasanudin et al., 2020). Pembelajaran sendiri merupakan jiwa institusi pendidikan yang mutunya wajib ditingkatkan secara terus-menerus. Peserta didik seyogyanya mendapatkan pengalaman belajar formal terbanyak selama mengikuti pembelajaran di sekolah (Nur Cholid, 2015). Pelajaran dirancang sedemikian rupa menggunakan strategi, metode, dan media pembelajaran yang terus berkembang (Jihad \& Haris, 2013).

Islam sangat menekankan pendidikan dan media pembelajaran. Banyak metode pembelajaran yang difirmankan Allah dalam Al-Quran, semisal dalam QS. Al-Maidah ayat 31 dijelaskan bahwa Allah menyuruh seekor burung gagak menggali-gali di bumi untuk memperlihatkan kepadanya (Qabil) bagaimana seharusnya menguburkan mayat saudaranya. Berkata Qabil: "Aduhai celaka aku, mengapa aku tidak mampu berbuat seperti burung gagak ini. Lalu aku dapat menguburkan mayat saudaraku ini?". Karena itu jadilah dia seorang diantara orang-orang yang menyesal (QS. Al-Maidah: 31) (Islam, n.d.).

Terkait dengan ayat tersebut, Fikih menjadi mata pelajaran sekaligus media untuk mengajarkan aspek penting sosial keagamaan yang berhubungan dengan kehidupan sehari-hari. Jiak anak memiliki sikap sosial yang baik pada umumnya memiliki emosi yang baik pula dan memiliki banyak teman (serli merlina). Oleh sebab itu pelajaran Fikih akan lebih efektif jika diberikan sejak usia dini. Menurut Al-Ghazali Fikih ialah hukum syariat yang berhubungan dengan perbuatan orang mukallaf, seperti: mengetahui hukum wajib, haram, mubah, mandup dan makruh; atau mengetahui suatu akad itu sah atau tidak; dan suatu ibadah itu diluar 
waktunya yang semestinya (qadla') atau di dalam waktunya (ada') (Subandi \& Dkk, 2012).

Minimnya variasi metode pengajaran yang dilakukan oleh guru mengakibatkan proses pembelajaran berlangsung kurang maksimal (Widiana \& Parera, 2019). Hal ini terbukti dari hasil observasi yang dilakukan peneliti pada pembelajaran Fikih kelas II di MI Roudhotul Huda. Saat mengajar guru masih terbiasa pada kebiasaan mengajar dengan menggunakan langkah-langkah pembelajaran seperti: menyajikan materi pembelajaran secara tekstual dan disajikan dengan menggunakan metode pengajaran konvensional dan ekspositori yakni memberikan contoh-contoh soal dan meminta siswa mengerjakan soal-soal latihan yang terdapat dalam buku teks yang mereka gunakan dalam mengajar dan kemudian membahasnya bersama-sama.

Salah satu cara untuk membantu proses pemahaman peserta didik dengan menggunakan media pembelajaran (Wijaya et al., 2020). Media adalah segala bentuk alat komunikasi yang dapat digunakan menyampaikan informasi dari sumber kepada peserta didik dan bertujuan agar peserta didik terangsang untuk mengikuti pembelajaran, memberi penguatan dan motivasi belajar (Munir, 2009). Media pembelajaran sebaiknya disesuaikan dengan perkembangan usia peserta didik supaya dalam penggunaan media dapat tepat sasaran dan tepat guna (Marlina, 2014).

Riset terdahulu berhasil membuktikan bahwa melalui penggunaan audio visual pembelajaran menjadi lebih menyenangkan dan bermakna. Seperti hasil penelitian pengembangan media audio visual berbasis animasi pada mata pelajaran Matematika materi bangun ruang. Kevalidan produk berdasarkan validasi ahli materi sebesar 3,64 termasuk kriteria "sangat layak" untuk digunakan, sedangkan berdasarkan validasi ahli media sebesar 3,84 termasuk kriteria "sangat layak" untuk digunakan, dan hasil ujicoba pada siswa kelas V sebesar 100\% termasuk kriteria "sangat baik" untuk digunakan (Khasanudin et al., 2020).

Keberhasilan media pembelajaran dalam upaya meningkatkan hasil belajar peserta didik juga terbukti pada hasil penelitian penggunaan media diorama materi pelajaran matematika dimana hasil pretest dengan mean sebesar 50,25 menjadi 89 dilihat dari hasil perhitungan posttest. Selain itu riset ini membuktikan juga 
bagaimana media pembelajaran berhasil mempengaruhi hasil belajar dengan besaran nilai koefisien determinasi ( $R_{\text {square }}$ ) 0,236 atau sama dengan 23,6\% (Aprilia $\&$ Putri, 2020).

Selanjutnya riset tentang Peranan Model Pembelajaran Value Clarification Technique Berbantuan Media Audio Visual Untuk Meningkatkan Hasil Belajar IPS mendukung untuk menjadi referensi karena hasil kegiatan pembelajaran pra siklus menghasilkan rerata kelas 56,38, dengan peserta didik yang tuntas sebanyak 10 atau 34,48\%. Hasil pengamatan menunjukkan siswa yang memiliki keberanian dan mampu jawab pertanyaan guru dengan benar baru 9 orang atau 31,03\%. Dari Kegiatan Siklus 1 diperoleh rerata kelas 68,28, dengan peserta didik yang tuntas sebanyak 17 orang atau 58,62\%. Hasil pengamatan menunjukkan siswa yang memiliki keberanian dan mampu menjawab pertanyaan guru dengan benar meningkat, mencapai 16 orang atau 55,17\%. Kegiatan Siklus 2 yang menggunakan Value Clarification Technique (VCT) dengan berbantuan media audio visual diperoleh hasil rerata kelas 86,72 dengan peserta didik yang tuntas sebanyak 27 orang peserta didik atau 93,10. Hasil pengamatan menunjukkan siswa yang memiliki keberanian dan mampu jawab pertanyaan guru dengan benar mencapai 26 orang atau 89,66\% (Sulfemi \& Mayasari, 2019).

Melihat keberhasilan riset terdahulu serta latar belakang permasalahan pembelajaran Fikih di MI Roudhotul Huda maka peneliti berinisiatif perlu upaya peningkatan hasil belajar dengan menggunakan media pembelajaran audio visual yang mampu menarik dan merangsang panca indera peserta didik.

\section{B. Metode Penelitian}

Jenis penelitian dalam penelitian ini termasuk dalam kategori penelitian tindakan. Metode yang digunakan dalam penelitian ini adalah metode penelitian tindakan kelas (classroom action research). Pemilihan metode penelitian tindakan kelas didasarkan atas dasar masalah dan tujuan penelitian yang menuntut adanya perbaikan/peningkatan (tindak lanjut) di dalam kelas. Subjek penelitian ini adalah seluruh siswa kelas II MI Roudhotul Huda Sekaran Kecamatan Gunungpati Semarang yang berjumlah 29 siswa yang terdiri dari 15 siswa putra dan 14 siswi 
putri. Sedangkan obyek penelitian ini adalah pembelajaran menggunakan media audio visual pada pelajaran Fikih.

Model PTK yang digunakan dalam penelitian ini adalah model Kemmis dan Mc.Taggart. Siklus penelitian ini tergantung pada ketercapaian tujuan penelitian, apabila tujuan penelitian telah tercapai maka siklus selanjutnya tidak dilakukan (Arikunto, 2006). Setiap siklus akan terdiri dari 4 tahap yaitu Planning (perencanaan), Acting (tindakan), Observasing (pengamatan), dan Reflecting (refleksi). Adapun desain pelaksanaan PTK menurut Kemmis dan Mc. Taggart dapat digambarkan sebagai berikut (Suyadi, 2012) :

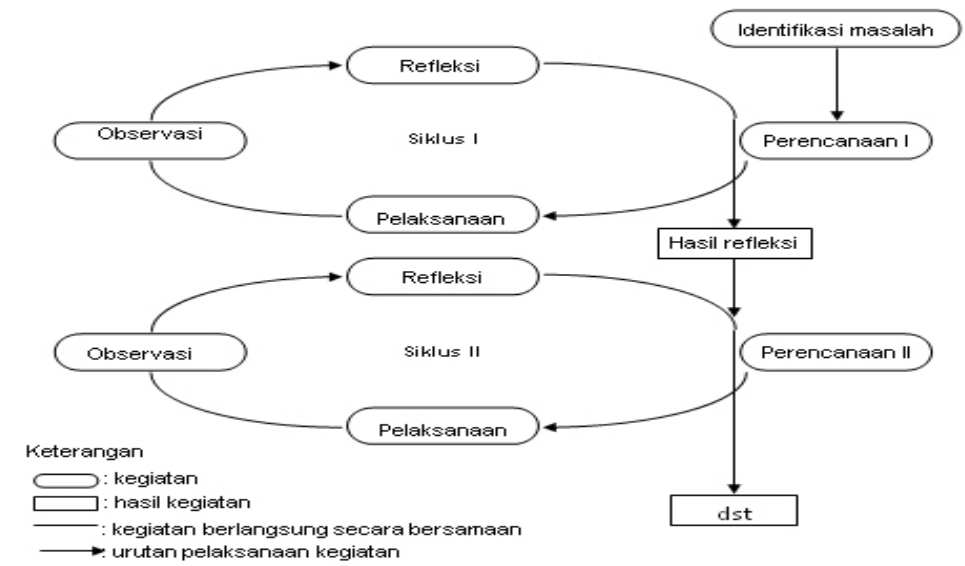

Gambar 1. Desain Penelitian Tindakan Kelas menurut Kemmis dan Mc.Taggart

\section{Hasil dan Pembahasan}

Pelaksanaan pembelajaran Fikih di MI Roudhotul Huda Sekaran Gunungpati selama berlangsung secara konvensional dan ekspositori. Guru menerangkan materi dari buku, kemudian siswa menirukan dan mempraktekkannya. Pembelajaran model seperti ini membuat guru lebih aktif dalam pembelajaran, menerangkan sejelas mungkin agar dipahami oleh siswa. Siswa menjadi pasif karena guru menjadi pusat belajar. Pembelajaran dewasa ini menuntut adanya inovasi dan siswa menjadi pembelajar yang aktif.

Sebelum melakukan penelitian, peneliti meminta nilai asli siswa sebelum diadakan perbaikan. Dari nilai murni siswa tersebut didapatkan bahwa siswa yang tuntas belajar sebanyak 11 orang. Siswa yang tidak tuntas pembelajarannya sebanyak 18 orang. Hanya 11 siswa yang tuntas pembelajaran, tetapi nilai yang mereka dapatkan sesuai standar KKM, yaitu nilai 70. Jumlah siswa yang tuntas 
dan tidak tuntas sesungguhnya tidak begitu mengecewakan, tapi karena untuk PTK, diupayakan semua siswa dapat tuntas dalam pembelajaran. Ketercapaian KKM dalam semester I adalah 38\%.

Tabel 1. Persentase Nilai Pelajaran Fikih Semester I

\begin{tabular}{|c|c|c|}
\hline Ketuntasan Belajar & Jumlah Siswa & Presentase \\
\hline Tuntas & 11 & $38 \%$ \\
\hline Tidak Tuntas & 18 & $62 \%$ \\
\hline Ketercapaian KKM & \multicolumn{2}{|c|}{$38 \%$} \\
\hline
\end{tabular}

Jumlah siswa yang mencapai ketuntasan belajar juga dapat dilihat dalam diagram batang berikut:

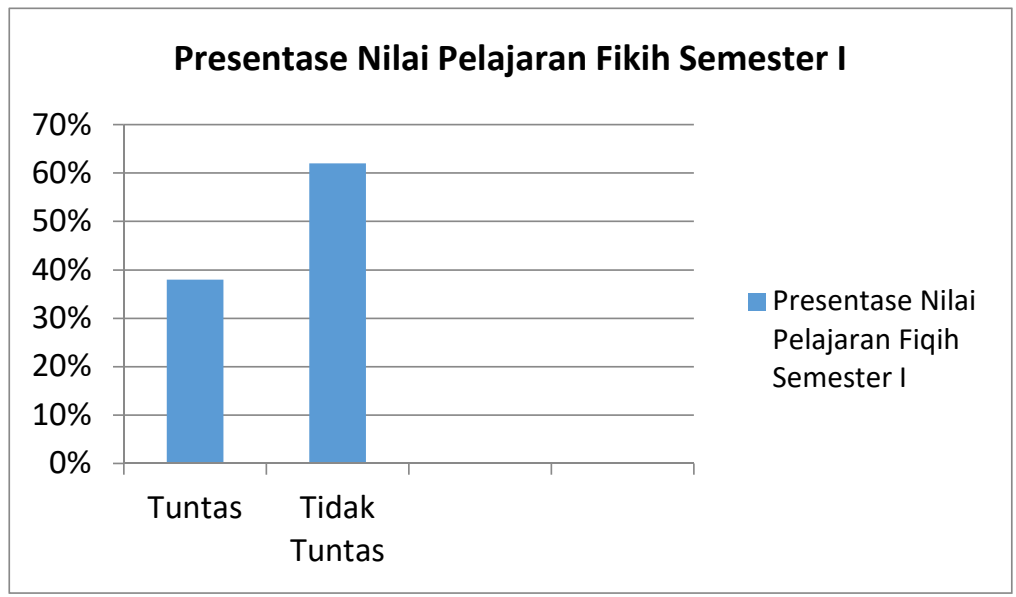

Gambar 2. Diagram hasil ketuntasan siswa pada Semester I

Berdasarkan dari nilai tersebut, peneliti melaksanakan Penelitian Tindakan Kelas untuk pelajaran Fikih kelas II MI dengan tema Indahnya Kebersamaan. Materi yang diajarkan adalah Sholat Berjamaah. Tujuan dari penelitian adalah untuk meningkatkan hasil belajar siswa agar 100 ketuntasan dalam belajar dapat tercapai.

Peneliti melakukan persiapan PTK, yang meliputi perencanaan, tindakan, dan refleksi. Perencanaan meliputi persiapan pembelajaran, persiapan media pembelajaran, dan persiapan silbus, RPP, observasi, dan lain-lain. Semua disiapkan agar PTK dapat berjalan maksimal dan nilai yang diperoleh siswa juga maksimal.

Peneliti merencanakan untuk melaksanakan PTK dalam tiga siklus. Pertimbangan ini didasarkan pada kondisi jumlah siswa yang cukup banyak. Untuk tiap siklus adalah 2 kali pertemuan, sehingga tiap kelompok dapat berpraktik dengan baik. Tiap PTK peneliti menyediakan lembar penilaian untuk 
evaluasi dan observasi. Lembar evaluasi digunakan untuk melihat perkembangan nilai siswa dari tiap siklus, apakah mengalami peningkatan atau tidak. Lembar observasi digunakan untuk melihat perhatian dan keaktifan siswa selama pembelajaran tiap siklus meningkat atau tidak.

Pada tahap tindakan siklus I, peneliti melaksanakan PTK dengan membagi siswa menjadi 5 kelompok. Pada tiga siklus yang dilaksanakan, kelompok diacak, sehingga pada tiap siklus, tiap kelompok berbeda-beda. Berdasarkan tindakan PTK yang dilakukan, prestasi belajar Fikih di kelas II MI Roudhotul Huda Sekaran Gunungpati belum $100 \%$ memenuhi KKM. Meskipun terpenuhi nilai-nilai tersebut masih sebatas pada nilai 70, yaitu nilai minimal KKM. Nilai siswa pada siklus I dapat dilihat dalam tabel di bawah ini.

Tabel 2. Persentase Nilai Siswa Setelah Siklus I

\begin{tabular}{|c|c|c|c|}
\hline \multicolumn{2}{|c|}{ Ketuntasan Belajar } & Jumlah Siswa & Presentase \\
\hline \multirow{3}{*}{ Tuntas } & Nilai 65 & 1 & $3 \%$ \\
\cline { 2 - 4 } & Nilai 70 & 15 & $52 \%$ \\
\cline { 2 - 4 } & Nilai 75 & 13 & $45 \%$ \\
\hline \multicolumn{2}{|c|}{ Tidak Tuntas } & 0 & $0 \%$ \\
\hline \multicolumn{2}{|c|}{ Ketercapaian KKM } & \multicolumn{2}{|c}{} \\
\hline
\end{tabular}

Meskipun ketercapaian KKM sudah 97\%, namun rentang nilainya hanya terpaut 5 poin. Sebanyak 15 siswa (52\%) mendapat nilai 70, standar minimal nilai KKM. Sebanyak 13 siswa mendapat nilai sebanyak 13 (45\%), dan hanya 1 siswa yang mendapat nilai di bawah KKM (65). Terjadi peningkatan yang pesat bahwa ketercapaian KKM semester 1 adalah 38\%, dan naik menjadi 97\% pada siklus I. Terjadi peningkatan 59\%. Namun nilai ini masih perlu ditingkatkan lagi.

Jumlah nilai nilai peserta didik pada siklus I dapat dilihat dalam diagram lingkaran berikut:

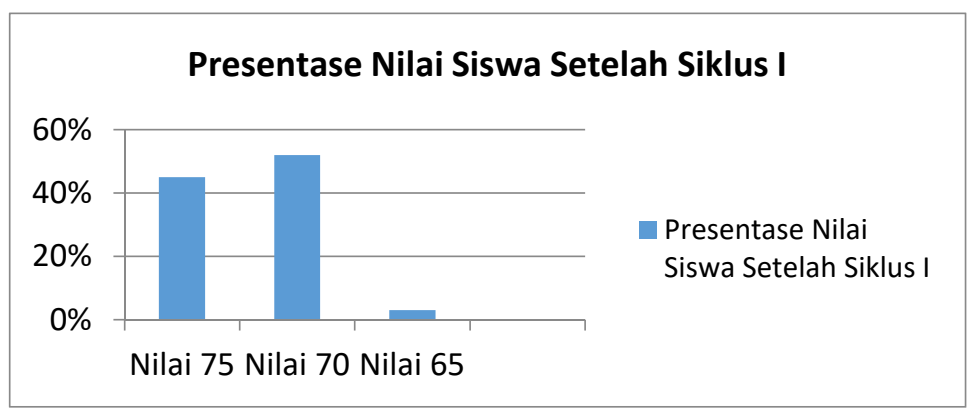

Gambar 3. Ketuntasan hasil belajar peserta didik pada siklus I 
Observasi siswa selama pembelajaran berlangsung menunjukkan bahwa keaktifan siswa tergolong cukup dan baik. Sebanyak 12 siswa (41\%) mendapat nilai 2, yaitu kategori cukup. Sedangkan siswa yang mendapat nilai 3 (baik) sebanyak 17 orang (59\%). Berdasarkan observasi pada keaktifan siswa pada siklus I, didapatkan nilai sebagaimana dalam tabel di bawah ini. Hasil tersebut tidak begitu mengecewakan, namun masih perlu ditingkatkan lagi pada siklus II. Pada akhir siklus I, peneliti melakukan refleksi pembelajaran sebagai bahan evaluasi untuk siklus II.

Tabel 3. Persentase Hasil Observasi Keaktifan Siswa Pada Siklus I

\begin{tabular}{|c|l|c|c|}
\hline Nilai & Keterangan & Jumlah siswa & Presentase \\
\hline 1 & Kurang & 0 & $0 \%$ \\
\hline 2 & Cukup & 12 & $41 \%$ \\
\hline 3 & Baik & 17 & $59 \%$ \\
\hline 4 & Sangat baik & 0 & $0 \%$ \\
\hline \multicolumn{2}{|c|}{ Jumlah } & $100 \%$ \\
\hline
\end{tabular}

Untuk diagram keaktifan siswa bisa dilihat pada gambar di bawah ini.

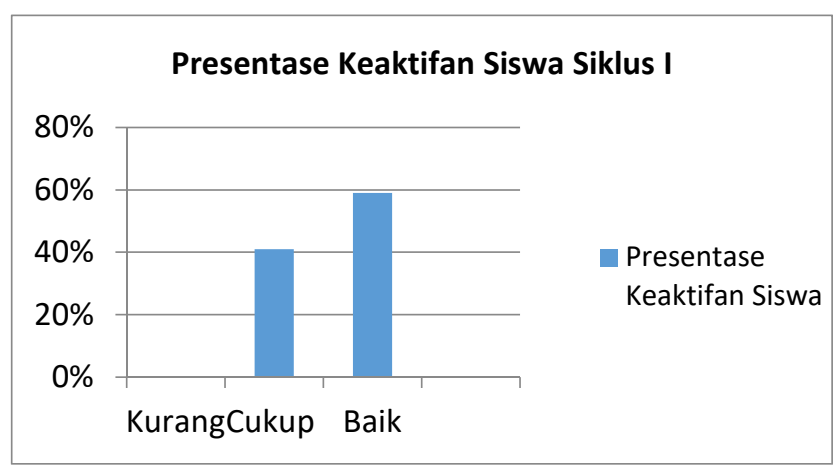

Gambar 4. Observasi keaktifan siswa pada siklus I

Sama seperti siklus I, pada pelaksanaan siklus II meliputi perencanaan, tindakan dan refleksi. Pada awal pembelajaran, peneliti menyampaikan apersepsi singkat yang merupakan hasil refleksi pada siklus I. Prestasi belajar siswa sudah meningkat, namun masih ada beberapa aspek yang masih perlu ditingkatkan lagi.

Kelas masih dibagi menjadi 5 kelompok dengan anggota yang berbeda dari siklus pertama. Untuk siklus II masih dilangsungkan dalam 2 kali pertemuan. Pertukaran anggota kelompok ini dimaksudkan untuk melihat apakah siswa dapat bekerja sama dengan teman-temannya. Peneliti meminta yang bertugas menjadi 
imam untuk melakukan kesalahan membaca ayat atau gerakan rukun shalat sehingga makmum akan mengingatkan imam yang lupa. Pada akhir siklus, peneliti melakukan evaluasi pembelajaran untuk mengukur apakah ada peningkatan prestasi belajar atau tidak. Berdasarkan hasil evaluasi, didapatkan nilai peserta didik sebagai berikut:

Tabel 4. Persentase Nilai Siswa pada Siklus II

\begin{tabular}{|c|c|c|c|}
\hline \multicolumn{2}{|c|}{ Ketuntasan Belajar } & Jumlah Siswa & Presentase \\
\hline \multirow{3}{*}{ Tuntas } & Nilai 70 & 1 & $3 \%$ \\
\cline { 2 - 4 } & Nilai 75 & 13 & $45 \%$ \\
\cline { 2 - 4 } & Nilai 80 & 15 & $52 \%$ \\
\hline \multicolumn{2}{|c|}{ Tidak Tuntas } & 0 & $0 \%$ \\
\hline \multicolumn{2}{|c|}{ Ketercapaian KKM } & 29 & $100 \%$ \\
\hline
\end{tabular}

Siklus II menghasilkan evaluasi pembelajaran yang memuaskan. Semua siswa tuntas dalam pembelajaran. tetapi nilai yang didapatkan hanya berkisar pada rentang 10 point. Nilai terendah siswa adalah 70 dicapai oleh 1 siswa(3\%), nilai 75 sebanyak 13 siswa (45\%) dan nilai 80 dicapai oleh 15 siswa (52\%). Hasil ini sudah memuaskan, namun belum ada siswa yang meraih nilai mendekati sempurna (100). Untuk itu siklus III akan dilaksanakan dengan pertimbangan melihat berapa siswa yang mampu mencapai nilai tertinggi.

Sepanjang pelaksanaan pembelajaran peneliti terus memotivasi dengan katakata penyemangat yang diharapkan membuat siswa semangat belajar. Melihat rentang nilai dalam evaluasi yang berjarak hanya 10 point dari nilai terendah dan tertinggi, artinya kemampuan siswa sebetulnya hampir merata.

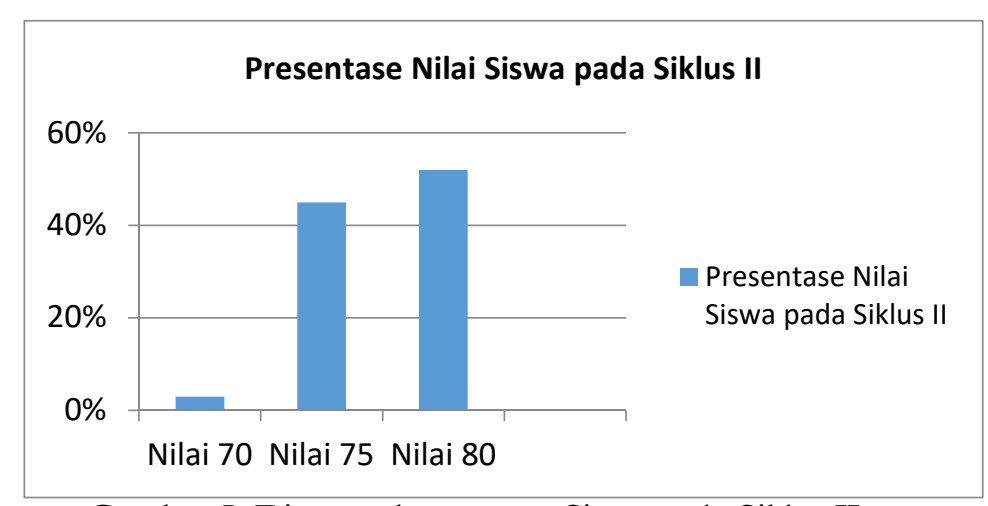

Gambar 5. Diagram ketuntasan Siswa pada Siklus II

Peneliti melakukan observasi pada siswa saat pembelajaran berlangsung. Aspek yang diamati bukan hanya saat siswa sedang praktik, tetapi juga saat tidak praktik. Karena kecenderungan anak ada yang justru aktif saat tidak mendapat tugas. Siswa yang mengganggu temannya yang sedang praktik shalat berjamaah 
akan ditegur agar tidak mengganggu temannya. Berdasarkan observasi pada siklus II didapatkan nilai sebagai berikut:

Tabel 5. Persentase Observasi Keaktifan Siswa Pada Siklus II

\begin{tabular}{|c|c|c|c|}
\hline Nilai & Keterangan & Jumlah siswa & Presentase \\
\hline 1 & Kurang & 0 & $0 \%$ \\
\hline 2 & Cukup & 0 & $0 \%$ \\
\hline 3 & Baik & 23 & $21 \%$ \\
\hline 4 & Sangat baik & 6 & $79 \%$ \\
\hline \multicolumn{2}{|c|}{ Jumlah } & 29 & $100 \%$ \\
\hline
\end{tabular}

Observasi siswa pada siklus II ini menunjukkan bahwa keaktifan siswa sudah baik. Sebanyak 23 siswa mendapat nilai 3 (baik) dan 6 siswa mendapat nilai 4 (sangat baik). Hasil sudah sangat menggembirakan karena tidak ada siswa yang berada dalam kategori kurang aktif dan cukup aktif. Artinya semua siswa memiliki antusiasme yang tinggi terhadap materi pembelajaran yang sedang berlangsung. Namun, itu masih bisa ditingkatkan lagi pada siklus III.

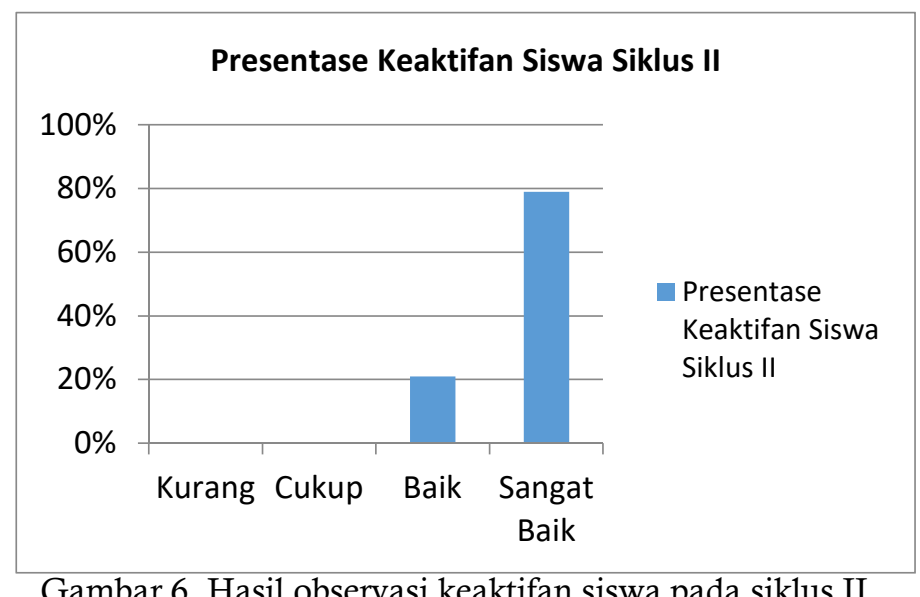

Gambar 6. Hasil observasi keaktifan siswa pada siklus II

Pada siklus III merupakan tahap akhir dalam pelaksanaan PTK ini. Pelaksanaan Siklus III ini meliputi perencanaan, tindakan, dan refleksi. Untuk perencanaan peneliti menyiapkan media pembelajaran, RPP, silabus, lembar penilaian dan observasi. Sebelum memulai pembelajaran, penelitian melakukan apersepsi untuk mengingat materi pada Siklus II. Hampir semua siswa dengan antusias menjawab masih mengingat. Peneliti membagi kelas menjadi 5 kelompok lagi dengan anggota yang berbeda. Tujuannya agar siswa dapat bekerja sama dengan teman-temannya. Pada akhir siklus, peneliti melakukan evaluasi untuk 
mengukur hasil belajar siswa. Ini merupakan penilaian akhir untuk PTK pembelajaran Fikih dengan media audio visual pada siswa kelas II MI Roudhotul Huda Sekaran Gunungpati semarang. Berdasarkan tes tertulis didapatkan nilai siswa untuk siklus III adalah sebagai berikut:

Tabel 6. Persentase Nilai Siswa Pada Siklus III

\begin{tabular}{|c|c|c|c|}
\hline \multicolumn{2}{|c|}{ Ketuntasan Belajar } & Jumlah Siswa & Presentase \\
\hline \multirow{4}{*}{ Tuntas } & Nilai 80 & 4 & $14 \%$ \\
\cline { 2 - 4 } & Nilai 85 & 7 & $24 \%$ \\
\cline { 2 - 4 } & Nilai 90 & 12 & $41 \%$ \\
\cline { 2 - 4 } & Nilai 95 & 6 & $21 \%$ \\
\hline \multicolumn{2}{|c|}{ Tidak Tuntas } & 0 & $0 \%$ \\
\hline \multicolumn{2}{|c|}{ Ketercapaian KKM } & 29 & $100 \%$ \\
\hline
\end{tabular}

Berdasarkan evaluasi pada siklus tiga, nilai siswa memiliki rentang 15 point. Nilai terendah adalah 80 yang dicapai 4 siswa (14\%), kemudian nilai 85 diraih oleh 7 siswa (24\%), nilai 90 siswa diraih oleh 12 siswa (41\%), dan nilai 95 diraih oleh 6 siswa (21\%). Hasil tersebut tentu sangat menggembirakan peneliti karena ada peningkatan hasil belajar. Meskipun tidak ada yang berhasil meraih nilai 100 .

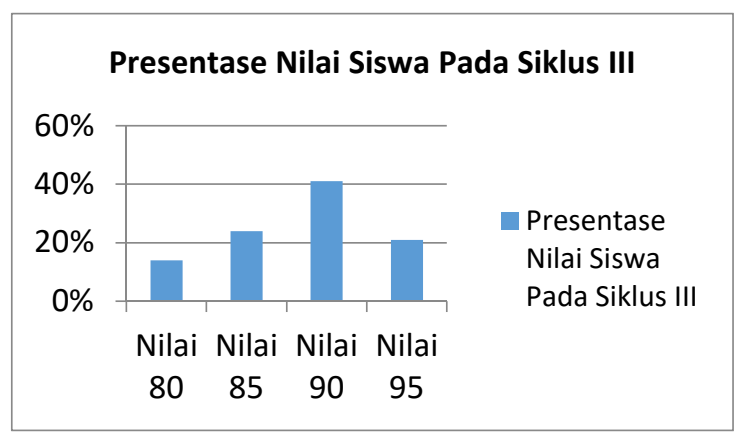

Gambar 7. Diagram ketuntasan hasil belajar peserta didik siklus III

Selain nilai tes di atas, nilai observasi juga mengalami peningkatan. Keaktifan siswa semakin meningkat pada siklus terakhir ini. Hal ini mungkin disebabkan siswa mulai berpikir bahwa mengganggu temannya itu tidak baik, membuat gaduh di kelas akan diperingatkan oleh guru, dan alasan-alasan lainnya. Hasil observasi siswa adalah sebagai berikut:

Tabel 7. Persentase Observasi Keaktifan Siswa Pada Siklus III

\begin{tabular}{|c|c|c|c|}
\hline Nilai & Keterangan & Jumlah siswa & Presentase \\
\hline 1 & Kurang & 0 & $0 \%$ \\
\hline 2 & Cukup & 0 & $0 \%$ \\
\hline 3 & Baik & 7 & $24 \%$ \\
\hline 4 & Sangat baik & 22 & $76 \%$ \\
\hline \multicolumn{2}{|c|}{ Jumlah } & 29 & $100 \%$ \\
\hline
\end{tabular}


Hasil observasi keaktifan siswa pada siklus III mengalami peningkatan, yaitu sebanyak 7 siswa (24\%) mendapat nilai 3 (baik) dan 22 siswa (76\%) mendapat nilai 4 (sangat baik). Hasil tersebut sangat menggembirakan karena siswa sangat aktif dalam pembelajaran.

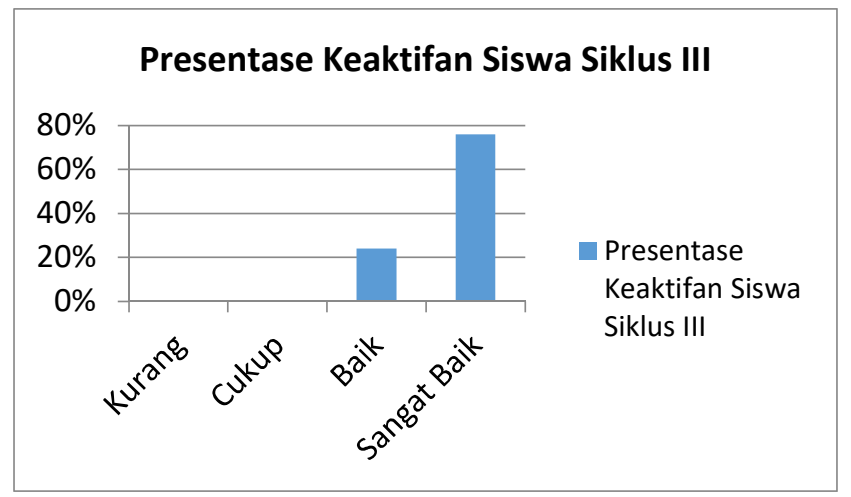

Gambar 8. Diagram hasil observasi keaktifan peserta didik pada Siklus III

Media pembelajaran Fikih dilakukan untuk menguji peningkatan prestasi belajar siswa pada pelajaran Fikih. Media audio visual cukup menarik minat perhatian siswa. Ketika guru memutar video, siswa tampak antusias. Berdasarkan penelitian tindakan kelas selama 3 siklus, terjadi peningkatan hasil belajar siswa. Persentase ketuntasan belajar pada semester I adalah 38\%. Pada siklus I sampai III mengalami peningkatan yang cukup signifikan. Pada siklus I KKM sudah mencapai 97\%. Masih ada 1 anak yang nilainya di bawah KKM. Pada siklus II dan III nilai KKM sudah mencapai $100 \%$. Namun rentang nilai tertinggi dan terendah hanya 10 poin (70-80). Pada siklus III terjadi peningkatan, dengan nilai terendah adalah 80 dan tertinggi adalah 95, dan belum ada siswa yang mencapai nilai 100 . Berikut adalah peningkatan persentase siswa sejak sebelum PTK dan setelah dilaksanakannya PTK dengan tiga kali siklus.

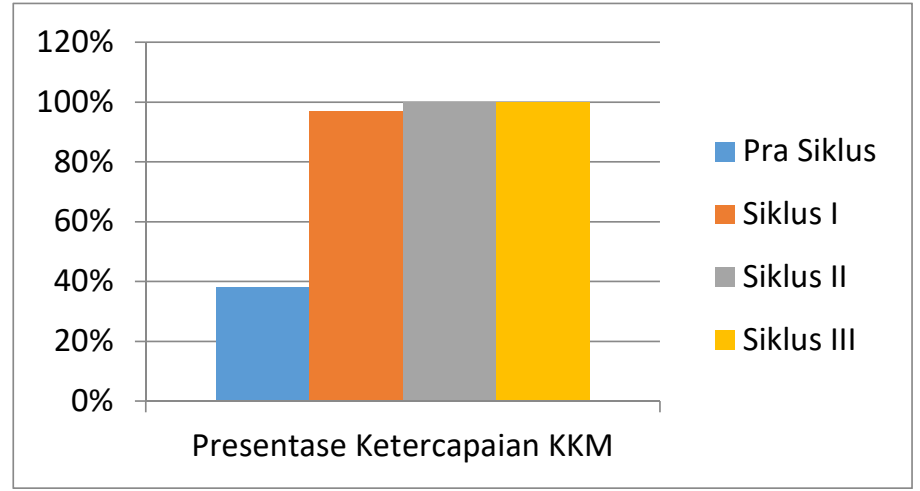

Gambar 8. Diagram perbandingan hasil belajar dari Pra siklus-siklus III 


\section{Kesimpulan}

Berdasarkan hasil penelitian dan analisis maka didapatkan kesimpulan bahwa pelaksanaan pembelajaran Fikih di kelas II MI Roudhotul Huda Sekaran Gunungpati mayoritas masih menggunakan model pembelajaran konvensional. Prestasi belajar siswa dalam pelajaran Fikih tema Indahnya Kebersamaan materi Shalat Berjamaah di kelas II MI Roudhotul Huda Sekaran Gunungpati dilaksanakan dengan tiga siklus. Peningkatan prestasi belajar adalah KKM sebelum PTK yaitu 38\%, dan meningkat menjadi 97\% pada siklus I dan 100\% pada siklus 2 dan tiga. Nilai terendah yang diraih siswa dalam siklus terakhir adalah 80 dan tertinggi adalah 95.

Peneliti ucapkan terima kasih pada pimpinan Fakultas Agama Islam Unwahas Semarang dan lembaga MI Roudhotul Huda yang telah memberikan arahan membangun demi terselesaikannya penelitian ini.

$* * * * * * * * *$

\section{Daftar Pustaka}

Ahmad Tafsir. (2004). Ilmu Pendidikan dalam Perspektif Islam. Remaja Rosdakarya.

Aprilia, H., \& Putri, L. I. (2020). Penggunaan media diorama: solusi pembelajaran matematika materi skala terhadap kemampuan berpikir tingkat tinggi jenjang dasar. Teorema: Teori Dan Riset Matematika, 5(September), 143-155.

Arikunto, S. (2006). Penelitian Tindakan Kelas. Bumi Aksara.

Dimyati dan Mudjiono. (2009). Belajar dan Pembelajaran. Rineka Cipta.

Islam, K. U. A. (n.d.). Alquran dan Terjemahanya. Kompleks Percetakan Alqur'an Raja Fahad.

Jihad, A., \& Haris, A. (2013). Evaluasi Pembelajaran. Multi Pressindo.

Khasanudin, M., Cholid, N., \& Putri, L. I. (2020). Pengembangan Media Audio Visual Pembelajaran. Collase: Creative of Learning Student Elementary Education, 3(5), 259-267.

Marlina, S. (2014). Peningkatan Sikap Sosial Anak Usia Dini Melalui Permainan Puzzle Puzzle Buah Di Taman Kanak-Kanak Aisyiyah 1 Bukittinggi. Jurnal Ilmiah Ilmu Pendidikan, XIV(2), 109-114.

Munir. (2009). Pembelajaran Jarak Jauh Berbasis Teknologi Informasi dan Komunikasi. Alfabeta.

Nur Cholid. (2015). Menjadi Guru Profesional. Presisi Cipta Media. 
Subandi, B., \& Dkk. (2012). Studi Hukum Islam. IAIN Sunan Ampel Press.

Sulfemi, W. B., \& Mayasari, N. (2019). The Use of Audio Visual Media in Value Clarification Technique to Improve Student Learning Outcomes in Social Studies. Jurnal Pendidikan, 20(1), 53-68.

Suyadi. (2012). Panduan Penelitian Tindakan Kelas. Diva Press.

Widiana, I. W., \& Parera, N. P. G. (2019). Media Permainan Ular Tangga Untuk Pengetahuan Ipa. 3, 315-322.

Wijaya, T. T., Murni, S., Purnama, A., \& Tanuwijaya, H. (2020). Pengembangan Media Pembelajaran Berbasis TPACK Menggunakan Hawgent Dynamic Mathematics Software. Journal of Elementary Education, 03(03), 64-72. 